\title{
Inhibitory Effects of Anti-Inflammatory Drugs on Interleukin-6 Bioactivity
}

\author{
Bo-Seong Kang, ${ }^{a}$ Eun-Yong Chung, ${ }^{a}$ Yeo-Pyo Yun, ${ }^{a}$ Myung Koo LeE, ${ }^{a}$ Yong Rok LeE, ${ }^{b}$ \\ Ki-Sung LeE, ${ }^{c}$ Kyung Rak Min, ${ }^{a}$ and Youngsoo KIM ${ }^{*, a}$ \\ College of Pharmacy, Chungbuk National University, ${ }^{a}$ Cheongju 361-763, Korea, College of Engineering, Yeungnam \\ University, ${ }^{b}$ Kyongsan 712-749, Korea, and Research Center for Biomedical Resources, Pai-Chai University, ${ }^{c}$ Taejon \\ 302-735, Korea. Received November 20, 2000; accepted February 14, 2001
}

\begin{abstract}
Interleukin-6 (IL-6) is known as a proinflammatory cytokine involved in immune response, inflammation, and hematopoiesis. Inhibitory effects of anti-inflammatory drugs on IL-6 bioactivity using IL-6-dependent hybridoma have been evaluated. Three out of 16 nonsteroidal anti-inflammatory drugs (NSAIDs) showed IC $_{50}$ values of less than $100 \mu_{\mathrm{M}}$, which were in the order of oxyphenylbutazone hydrate $\left(\mathrm{IC}_{50}=7.5 \mu_{\mathrm{M}}\right)>$ meclofenamic acid sodium salt $(31.9 \mu \mathrm{M})>$ sulindac $(74.9 \mu \mathrm{M})$. Steroidal anti-inflammatory drugs (SAIDs) exhibited significant inhibitory effects at $100 \mu_{\mathrm{M}}$ on the IL-6 bioactivity, and their inhibitory potencies were in the order of budesonide $\left(\mathrm{IC}_{50}=2.2 \mu \mathrm{M}\right)>$ hydrocortisone 21 -hemisuccinate $(6.7 \mu \mathrm{M})$, prednisolone $(7.5 \mu \mathrm{M})$, betamethasone $(10.9 \mu \mathrm{M})>\mathrm{dex}-$ amethasone $\left(18.9 \mu_{\mathrm{M}}\right)$ and triamcinolone acetonide $\left(24.1 \mu_{\mathrm{M}}\right)$. The results would provide an additional mechanism by which anti-inflammatory drugs display their anti-inflammatory and immunosuppressive effects at higher concentrations.
\end{abstract}

Key words anti-inflammatory drugs; IL-6 inhibitor; oxyphenylbutazone hydrate; budesonide

Interleukin-6 (IL-6) is a proinflammatory cytokine which is produced by both lymphoid and nonlymphoid cells. ${ }^{1)}$ The receptor for IL-6 is composed of two polypeptide chains called $\alpha$-subunit and $\beta$-subunit. ${ }^{1,2)}$ The $\alpha$-subunit is the ligand-binding chain with a molecular weight of approximately $80 \mathrm{kDa}$, and is also known as gp $800^{2,3)}$ The $\beta$-subunit is known as gp130 and is the signal-transducing chain of the receptor complex. ${ }^{2,4)}$ The gp130 is shared by a family of cytokines including oncostatin M (OSM), leukemia inhibitory factor (LIF), IL-11, cardiotrophin-1 (CT-1) and ciliary neurotrophic factor (CNTF). ${ }^{5-7)}$

IL-6 is a multifunctional cytokine acting in various cells. It induces the differentiation of B cells to antibody-producing plasma cells, T-cell growth and differentiation, the differentiation of myeloid leukemic cell lines into macrophages, megakaryocyte maturation, the neuronal differentiation of PC12 cells, development of osteoclasts, and acute-phase protein synthesis in hepatocytes. ${ }^{8-14)}$ IL-6 acts as a growth factor for myeloma/plasmacytoma, keratinocytes, mesangial cells, renal carcinoma, and Kaposi's sarcoma, but inhibits the growth of myeloid leukemia cell lines and certain sarcoma cell lines. ${ }^{15,16)}$ Thereby, IL-6 plays important roles in the pathogenesis of a variety of diseases, in particular, chronic inflammation, autoimmune diseases, viral infection, and malignancies. $^{1,2)}$

In this study, inhibitory effects of anti-inflammatory drugs on IL-6 bioactivity were investigated. Oxyphenybutazone hydrate exhibited the highest inhibitory effect among nonsteroidal anti-inflammatory drugs (NSAIDs) and budesonide among steroidal anti-inflammatory drugs (SAIDs).

\section{MATERIALS AND METHODS}

Materials Anti-inflammatory drugs, RPMI-1640, and 3[4,5-dimethylthiazol-2-yl]-2,5-diphenyltetrazolium bromide (MTT) were purchased from Sigma Chemical Co., Inc. (St. Louis, MO, U.S.A.). Fetal bovine serum (FBS) and $N$-[2-hydroxyethyl]piperazine- $N$ '-2-ethanesulfonic acid (HEPES) were purchased from GIBCO BRL Products (Gaithersburg, MD, U.S.A.) and rhIL-6 from Wako Pure Chemical Ind., Ltd. (Osaka, Japan).

Culture of Hybridoma MH60/BSF-2 The murine B cell hybridoma dependent on IL-6 for its growth was cultured in RPMI $(10.4 \mathrm{mg} / \mathrm{ml}$ RPMI-1640, $2.48 \mathrm{mg} / \mathrm{ml}$ HEPES, $100 \mathrm{units} / \mathrm{ml}$ benzylpenicillin potassium, $100 \mu \mathrm{g} / \mathrm{ml}$ streptomycin sulfate, $\mathrm{pH} 7.1$ ) containing $10 \% \mathrm{FBS}$ and 1 unit $/ \mathrm{ml}$ rhIL-6 at $37^{\circ} \mathrm{C}$ with $5 \% \mathrm{CO}_{2}{ }^{17)}$

IL-6 Bioassay One hundred microliter of $1 \times 10^{4}$ MH60/BSF-2 cells, $50 \mu \mathrm{l}$ of $1.2 \mathrm{unit} / \mathrm{ml}$ rhIL-6, and $50 \mu \mathrm{l}$ of the medium with or without sample were added to a 96-well microplate (Nunc, Roskilde, Denmark). After incubation at $37^{\circ} \mathrm{C}$ with $5 \% \mathrm{CO}_{2}$ for $48 \mathrm{~h}$, the cell growth was measured by optical density (OD) at wavelength $570 \mathrm{~nm}$ using the MTT method. Effect on IL-6 bioactivity by the sample is represented as inhibition \%, [1-(sample $\mathrm{OD}_{570} /$ control $\left.\left.\mathrm{OD}_{570}\right)\right] \times 100$, compared with the control. Data are expressed as means \pm S.E.M., and their significant differences from the controls were analyzed by Student's $t$-test.

IL-3 Bioassay and Cytotoxicity BAF/BO3 cell line was cultured in RPMI containing 10\% FBS and 20 units $/ \mathrm{ml}$ rmIL-3. Proliferation of BAF/BO3 by rmIL-3 was measured as an IL-3 bioassay. ${ }^{18)}$ IL-6-independent MH60 cell line was established by gradually decreasing IL-6 in RPMI containing $10 \%$ FBS for passage of MH60/BSF-2. ${ }^{18)}$ Effect on the growth rate of IL-6-independent MH60 cells in RPMI containing 10\% FBS without IL-6 was viewed as the cytotoxicity of the sample.

\section{RESULTS AND DISCUSSION}

NSAIDs are well known as inhibitors of prostaglandin synthesis. However, the mechanism may not account for all pharmacological effects of NSAIDs. It was reported that indomethacin and diclofenac up-regulated the production of TNF, IFN- $\gamma$ and IL-2 released from Th1 cells but down-regulated the production of IL-4 and IL- 6 released from Th2 
cells. ${ }^{19)}$

Five NSAIDs of diclofenac sodium salt, sulindac, meclofenamic acid sodium salt, mefenamic acid and oxyphenylbutazone hydrate exhibited significant inhibitory effects at 100 $\mu \mathrm{M}$ on IL-6 bioactivity (Table 1). Diclofenac sodium salts and sulindac at $100 \mu \mathrm{M}$ exhibited $42 \%$ and $79 \%$ inhibition on the cytokine bioactivity, respectively, but etodolac, indomethacin, and tolmetin sodium salt in the acetate subfamily of NSAIDs did not inhibit. Both meclofenamic acid sodium salt and mefenamic acid in the fenamate subfamily exhibited $>95 \%$ and $37 \%$ inhibition at $100 \mu \mathrm{M}$, respectively. Oxyphenylbutazone hydrate exhibited $>95 \%$ inhibition at $100 \mu \mathrm{M}$ on IL- 6 bioactivity, but phenylbutazone in the pyrazoline subfamily did not inhibit. None of NSAIDs in carboxylate, propionate and oxicam subfamilies tested in this study showed significant inhibitory effects on IL-6 bioactivity. Oxyphenylbutazone hydrate inhibited the IL-6 bioactivity in a dose-dependent manner, and showed an $\mathrm{IC}_{50}$ value at the concentration of $7.5 \mu \mathrm{M}$ (Fig. 1). Based on the $\mathrm{IC}_{50}$ values, inhibitory potency on IL-6 bioactivity was in the order of oxyphenylbutazone hydrate $>$ meclofenamic acid sodium salt $>$ sulindac $>$ diclofenac sodium salt and mefenamic acid (Table 1).

SAIDs are corticosteroids exerting profound effects on the inflammatory and immune responses. ${ }^{20)}$ Corticosteroid responses are initiated by binding to a specific receptor, and mediated by the cascade of cellular events involving synthe-

Table 1. Inhibitory Effects on IL-6 Bioactivity

\begin{tabular}{|c|c|c|}
\hline Anti-inflammatory drug & $\begin{array}{c}\text { Inhibition }(\%) \\
\text { at } 100 \mu \mathrm{M}\end{array}$ & $\mathrm{IC}_{50}(\mu \mathrm{M})$ \\
\hline \multicolumn{3}{|l|}{ Nonsteroidal anti-inflammatory drugs } \\
\hline \multicolumn{3}{|l|}{ Carboxylate } \\
\hline Aspirin & $<0 \pm 3$ & $>100$ \\
\hline \multicolumn{3}{|l|}{ Acetates } \\
\hline Diclofenac sodium salt & $42 \pm 2 *$ & $>100$ \\
\hline Etodolac & $19 \pm 3$ & $>100$ \\
\hline Indomethacin & $19 \pm 1$ & $>100$ \\
\hline Sulindac & $79 \pm 1 *$ & 74.9 \\
\hline Tolmetin sodium salt & $8 \pm 6$ & $>100$ \\
\hline \multicolumn{3}{|l|}{ Propionates } \\
\hline Fenoprofen calcium salt & $16 \pm 2$ & $>100$ \\
\hline Flurbiprofen & $26 \pm 3$ & $>100$ \\
\hline Ibuprofen & $<0 \pm 1$ & $>100$ \\
\hline Ketoprofen & $<0 \pm 4$ & $>100$ \\
\hline Naproxen sodium salt & $18 \pm 4$ & $>100$ \\
\hline \multicolumn{3}{|l|}{ Fenamates } \\
\hline Meclofenamic acid sodium salt & $>95 \pm 1 *$ & 31.9 \\
\hline Mefenamic acid & $37 \pm 3 *$ & $>100$ \\
\hline \multicolumn{3}{|l|}{ Pyrazolines } \\
\hline Oxyphenylbutazone hydrate & $>95 \pm 1 *$ & 7.5 \\
\hline Phenylbutazone & $26 \pm 4$ & $>100$ \\
\hline \multicolumn{3}{|l|}{ Oxicam } \\
\hline Piroxicam & $12 \pm 1$ & $>100$ \\
\hline \multicolumn{3}{|l|}{ Steroidal anti-inflammatory drugs } \\
\hline Beclomethasone dipropionate & $45 \pm 2 *$ & $>100$ \\
\hline Betamethasone & $93 \pm 2 *$ & 10.9 \\
\hline Budesonide & $>95 \pm 4^{*}$ & 2.2 \\
\hline Dexamethasone & $>95 \pm 1 *$ & 18.9 \\
\hline Hydrocortisone 21-hemisuccinate & $92 \pm 2 *$ & 6.7 \\
\hline Prednisolone & $>95 \pm 3 *$ & 7.5 \\
\hline Triamcinolone acetonide & $86 \pm 4 *$ & 24.1 \\
\hline
\end{tabular}

IL-6 bioactivity was measured by proliferation of hybridoma MH60/BSF-2 in the presence of rhIL-6. Data are represented as inhibition $\%$, mean \pm S.E. of three independent tests, and their significant differences from the control are $* p<0.001$. sis of new proteins. It was reported that SAIDs inhibited the production of TNF, IL-1, IL-2, IL-6, IFN- $\gamma$ chemokine, and GM-CSF, but increased the number of receptors of IL-1 and IL-6. ${ }^{20)}$

All SAIDs exhibited significant inhibitory effects at 100 $\mu \mathrm{M}$ on IL-6 bioactivity (Table 1 ). Based on the $\mathrm{IC}_{50}$ values, inhibitory potency on IL-6 bioactivity was in the order of budesonide $>$ hydrocortisone 21-hemisuccinate, prednisolone, betamethasone $>$ dexamethasone, triamcinolone acetonide $>$ beclomethasone dipropionate. Budesonide inhibited the IL-6 bioactivity in a dose-dependent manner, and showed an $\mathrm{IC}_{50}$ value at the concentration of $2.2 \mu \mathrm{M}$ (Fig. 1).

Among anti-inflammatory drugs showing $>50 \%$ inhibition on IL-6 bioactivity at $100 \mu \mathrm{M}$, all except sulindac and budesonide inhibited the IL-3 bioactivity with potency in the order of prednisolone, hydrocortisone 21-hemisuccinate, dexamethasone>oxyphenylbutazone hydrate, triamcinolone ace-

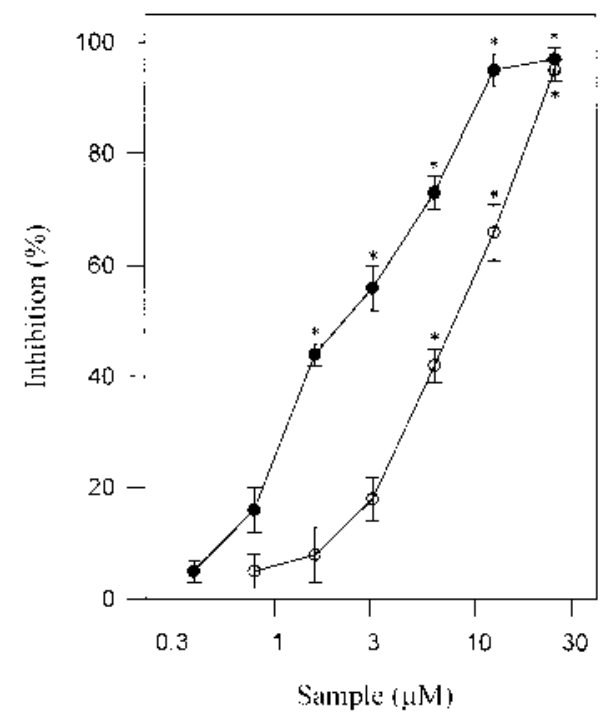

Fig. 1. Dose-Dependent Inhibitory Effects on IL-6 Bioactivity by Oxyphenylbutazone Hydrate and Budesonide

Samples are oxyphenylbutazone hydrate (open circle) and budesonide (solid circle). Data are represented as inhibition $\%$, mean \pm S.E. of three independent tests, and their significant differences from the control are $* p<0.001$.

Table 2. Inhibitory Effects on IL-3 Bioactivity and Cytotoxic Effects on IL-6-independent MH60 Cells

\begin{tabular}{lcc}
\hline \hline \multirow{2}{*}{ Anti-inflammatory drug } & \multicolumn{2}{c}{$\mathrm{IC}_{50}(\mu \mathrm{M})$} \\
\cline { 2 - 3 } & $\mathrm{IL}-3$ & Cytotoxicity \\
\hline Nonsteroidal anti-inflammatory drugs & & \\
Sulindac & $>100$ & $>100$ \\
Meclofenamic acid sodium salt & 48.6 & 92.7 \\
Oxyphenylbutazone hydrate & 35.2 & 78.5 \\
Steroidal anti-inflammatory drugs & & \\
Betamethasone & 51.0 & $>100$ \\
Budesonide & $>100$ & $>100$ \\
Dexamethasone & 24.9 & $>100$ \\
Hydrocortisone 21-hemisuccinate & 21.4 & $>100$ \\
Prednisolone & 16.0 & $>100$ \\
Triamcinolone acetonide & 39.9 & $>100$ \\
\hline
\end{tabular}

IL-3 bioactivity was measured by proliferation of $\mathrm{BAF} / \mathrm{BO} 3$ cells in the presence of rmIL-3. Cytotoxicity was measured by inhibitory effects on the growth rate of IL-6-independent MH60 cells in RPMI containing 10\% FBS without IL-6. Data are represented as $50 \%$ inhibition $\left(\mathrm{IC}_{50}\right)$ at micromolar concentration. 
tonide $>$ meclofenamic acid sodium salt and betamethasone (Table 2). None of the compounds except oxyphenylbutazone hydrate and meclofenamic acid sodium salt showed cytotoxic effects on IL-6-independent MH60 cells (Table 2).

Several types of potential pharmaceutical agents which inhibit IL-6 synthesis or signaling have been reported including tenidap, suramin, suplatast tosylates, herbal extract of Stephania tetrandra, and marine extract of Erylus placenta. $^{21)}$ Tenidap is a NSAID-like agent with an inhibitory effect on IL-6 production and exhibited inhibitory effects on acute-phase response and rheumatoid arthritis, for which IL6 is a major mediator. ${ }^{22)}$

In this study, inhibitory effects of anti-inflammatory drugs on IL-6 bioactivity were demonstrated. Oxyphenylbutazone hydrate among NSAIDs exhibited the highest inhibitory effect with an $\mathrm{IC}_{50}$ value of $7.5 \mu \mathrm{M}$, and budesonide among SAIDs showed an $\mathrm{IC}_{50}$ value of $2.2 \mu \mathrm{M}$. These results would provide an additional mechanism by which the drugs exert their anti-inflammatory and immunosuppressive effects.

Acknowledgements The murine hybridoma MH60/ BSF-2 was kindly supplied by Dr. Toshio Hirano at Osaka University Medical School, Japan. This work was financially supported by a grant (KRF-99-042-F00167) from the Korea Research Foundation.

\section{REFERENCES}

1) Van Snick J., Annu. Rev. Immunol., 8, 253-278 (1990).

2) Hirano T., Int. J. Immunol., 16, 249-284 (1998).

3) Taga T., Hibi M., Yamasaki K., Yasukawa K., Matsuda T., Hirano T., Kishimoto T., Cell, 58, 573-581 (1989).

4) Hibi M., Murakami M., Saito M., Hirano T., Taga T., Kishimoto T., Cell, 63, 1149-1157 (1990).

5) Gearing D. P., Comeau M. R., Friend D. J., Thut C. J., Mcgourty J.,
Brasher K. K., King J. A., Gills S., Mosley B., Ziagler S. F., Cosman D., Science, 255, 1434-1437 (1992).

6) Yin T., Taga T., Tsang M. L.-S., Yasukawa K., Kishimoto T., Yang Y.C., J. Immunol., 151, 2555-2561 (1993).

7) Taga T., Narazaki M., Yasukawa K., Saito T., Miki D., Hamaguchi M., Davis S., Shoyab M., Yancopoulos G. D., Kishimoto T., Proc. Natl. Acad. Sci. U.S.A., 89, 10998-11001 (1992).

8) Ramsay A. J., Husband A. J., Ramshaw I. A., Bao S., Matthaei K. I., Koehler G., Kopf M., Science, 264, 561-563 (1994).

9) Takai Y., Wong G. G., Clark S. C., Burakoff S. J., Herrmann S. H., J. Immunol., 140, 508-512 (1988).

10) Shabo Y., Lotem J., Rubinstein M., Revel M., Clark S. C., Wolf S. F., Kamen R., Sachs L., Blood, 72, 2070-2073 (1988).

11) Ishibashi T., Kimura H., Uchida T., Kariyone S., Friese P., Burstein S. A., Proc. Natl. Acad. Sci. U.S.A., 86, 5953-5957 (1989).

12) Satoh T., Nakamura S., Taga T., Matsuda T., Hirano T., Kishimoto T., Kaziro Y., Mol. Cell Biol. 8, 3546-3549 (1988).

13) Poli V., Balena R., Fattori E., Markatos A., Yamamoto M., Tanaka H., Ciliberto G., Rodan G. A., Costantini F., EMBO J., 13, 1189-1196 (1994).

14) Kopf M., Baumann H., Freer G., Fredenberg M., Lamers M., Kishimoto T., Zinkernagel R., Bluethman H., Kohler G., Nature (London), 368, 339-342 (1994).

15) Kawano M., Hirano T., Matsuda T., Taga T., Horii Y., Iwato K., Asaoku H., Tang B., Tanabe O., Tanaka H., Kuramoto A., Kishimoto T., Nature (London), 332, 83-85 (1988).

16) Miki S., Iwano M., Miki Y., Yamamoto M., Tang B., Yokokawa K., Sonoda T., Hirano T., Kishimoto T., FEBS Lett., 250, 607-610 (1989).

17) Matsuda T., Hirano T., Kishimoto T., Eur. J. Immunol., 18, 951-956 (1988).

18) Yun J., Lee C.-K., Chang I.-M., Takatsu K., Hirano T., Min K. R., Lee M. K., Kim Y., Life Sci., 67, 2855-2863 (2000).

19) Tsuboi I., Tanaka H., Nakao M., Shichijo S., Itoh K., Cytokine, 4, 372-379 (1995).

20) Goldstein R. A., Bowen D. L., Fauci A. S., "Inflammation Basic Principles and Clinical Correlates," ed. by Gallin J. I., Goldstein I. M., Snyderman R., Raven Press, New York, 1992, pp. 1061-1082.

21) Barton B. E., Tagat J. R., Drugs Fut., 22, 391-395 (1997).

22) Sipe J. D., Bartle L. M., Loose L. D., J. Immunol., 148, 480-484 (1992). 